\title{
Tamburrini por Caetano: del testimonio al film de terror
}

\author{
Crónica de una fuga | Israel Adrián Caetano | 2006
}

Alfredo Dillon*

Universidad Católica Argentina, Argentina

Recibido: 28 de diciembre 2017; aceptado: 19 de abril 2018

\begin{abstract}
Resumen
El propósito de este trabajo es analizar el proceso de transposición fílmica del testimonio de Claudio Tamburrini, Pase libre. La fuga de la Mansión Seré(2002), que dio lugar a la película Crónica de una fuga (2006), de Israel Adrián Caetano. El artículo aborda el problema del punto de vista en la adaptación de un testimonio en primera persona, así como la utilización del género de terror para dar cuenta de los campos de concentración de la última dictadura cívico militar (1976-1983). También se aborda la construcción de los personajes y los efectos de la suspensión del juicio moral dentro del centro clandestino de detención y tortura. Finalmente, se discuten los límites en la representación -literaria o audiovisual- del horror, frente a las posibilidades de la espectacularización y el sensacionalismo.
\end{abstract}

Palabras Clave: Adaptación | transposición cinematográfica | testimonio | cine de terror | Crónica de una fuga

Tamburrini by Caetano: from testimony to horror film

\begin{abstract}
The aim of this article is to analyze the process of filmic adaptation of Claudio Tamburrini’s testimony, Pase libre. La fuga de la Mansión Seré (2002), into Israel Adrián Caetano's Chronicle of an Escape (Crónica de una fuga, 2006). The paper considers the problem of transformation of point of view in the transposition of a first person testimony, as well as the use of horror genre codes in the cinematographic representation of concentration camps in Argentina's last military dictatorship (1976-1983). The construction of characters and the effects of suspension of morality inside the clandestine center of detention and torture are also studied. Finally, the article discusses the limits of literary and audiovisual representation of horror, in order to avoid spectacularization and sensationalism.
\end{abstract}

Key Words: Adaptation | cinematographic transposition | testimony | horror films | Chronicle of an Escape

\section{Introducción}

En Crónica de una fuga (2006), Israel Adrián Caetano relata la huida de cuatro prisioneros de la Mansión Seré, uno de los centros clandestinos de detención y tortura de la última dictadura cívico-militar, ubicado en la zona Oeste del Gran Buenos Aires. A diferencia de la mayoría de las transposiciones cinematográficas, aquí el hipotexto no es ficcional: la película está basada en un relato testimonial, el libro Pase libre. La fuga de la Mansión Seré, de Claudio Tamburrini, uno de los detenidos que lograron fugarse en 1978.

Tamburrini tuvo que exiliarse tras la fuga y desde 1979 vive en Suecia, aunque regresó a la Argentina para testificar en el Juicio a las Juntas en 1985, durante el cual fue asesor del fiscal Julio Strassera. El autor no participó de la adaptación de su libro, encargada a Caetano por la productora K\&S Films. Quien sí tuvo una participación en el proceso fue Guillermo Fernández, el otro protagonista de la historia, a quien tanto Caetano como el propio Tamburrini consultaron para realizar sus obras ("Gran parte del material presentado en esta novela ha sido recuperado del olvido durante mis charlas con Guillermo Fernández" [7] $]^{1}$, señala Tamburrini en los agradecimientos). En la película, Fernández incluso interpreta un personaje menor: el de un represor que se hace pasar por juez.

El estreno de Crónica... en abril de 2006 coincidió con el $30^{\circ}$ aniversario del golpe militar del 24 de marzo de 1976. Fue una de las cinco películas argentinas más taquilleras de 2006, con más de 190 mil espectadores. Pase libre. La fuga de la mansión Seré fue publicado por primera vez en 2002 por Ediciones Continente. En 2006, de la mano del estreno de la película, salió la tercera edición, en

alfredodillon@yahoo.com 
cuya portada se modificó el título de la obra para reforzar el vínculo con el film: el nuevo nombre fue Pase libre. Crónica de una fuga, mientras que la contratapa señalaba que se trataba de "la novela testimonial llevada al cine".

$\mathrm{Al}$ presentarse como crónica, la película indica un compromiso con lo real, a la vez que supone una inscripción genérica: el espectador asume que se encuentra ante un relato del orden de lo verídico. Una placa en el comienzo lo aclara: "Esta historia está basada en el testimonio de dos víctimas". La película se presenta como una "versión libre" del testimonio de Tamburrini: en consecuencia, exige un pacto de lectura completamente diferente del de otras películas sobre la dictadura, sustentado en la veracidad de los hechos, y en función del cual la experiencia de visionado resulta mucho más inquietante para el espectador.

Nos encontramos, entonces, frente a la adaptación cinematográfica de un testimonio, una figura que ha sido profusamente analizada por autores como Primo Levi, Paul Ricoeur y Giorgio Agamben. Se ha hablado incluso de la "era del testigo", según la definición propuesta por Annette Wieviorka (cit. en Jelin, 2002) frente a la explosión testimonial a partir de la segunda mitad del siglo XX. El testimonio plantea una relación estrecha entre narración y experiencia: como plantea Sarlo, "no hay testimonio sin experiencia, pero tampoco hay experiencia sin narración" (2005: 29). En ese sentido, según explica el propio Tamburrini en su "Prólogo", lo que legitima el relato en Pase libre y Crónica de una fuga es "el punto de vista privilegiado de un protagonista” (10).

Caetano es uno de los nombres fundacionales del denominado Nuevo Cine Argentino, que para Aguilar (2010) constituye un nuevo régimen creativo caracterizado por rupturas fundamentales tanto en terreno de la producción como en el de la estética. Las películas de Caetano han recorrido los principales festivales internacionales y ganaron numerosos premios. Su ópera prima, $P i-$ zza, birra, faso (1998), codirigida por Bruno Stagnaro, es considerada el hito fundacional de la renovación del cine nacional a fines de los años noventa. Ese largometraje fue seguido por Bolivia (2001), Un oso rojo (2002), Crónica de una fuga (2006), Francia (2009), Mala (2013) y El otro hermano (2017), además de NK: El documental (2011, no estrenado comercialmente). De todas las "ficciones" de Caetano, las únicas adaptaciones fueron Crónica de una fuga y El otro hermano, basada en la novela Bajo este sol tremendo (2009), de Carlos Busqued.

La obra de Caetano ha sido definida como "cine del margen” (Mullaly, 2009: 160). En su universo narrativo, los lazos sociales están al límite de la desintegración; y cuando las fronteras entre el centro y el margen parecen en riesgo de desvanecerse definitivamente, la violencia surge con toda su contundencia para restablecer las diferencias. Entre los referentes del Nuevo Cine Argentino, ninguno explora la violencia con la precisión y minuciosidad del director uruguayo.

Esa exploración atraviesa toda la obra cinematográfica de Caetano, desde Pizza, birra, faso hasta El otro hermano. ${ }^{2}$ También la historia de Tumberos, la serie televisiva dirigida por Caetano en 2002, aparece marcada por una violencia que se desborda en el desenlace. El principal desafío estético de Crónica de una fuga es precisamente ese: cómo representar la violencia del terror durante la última dictadura militar.

\section{Crónica e historia}

Aunque la mayoría de los estudios académicos sobre el cine argentino contemporáneo enfatizan su interés por las "huellas del presente" (Aguilar, 2010: 8) y el impacto de la crisis de comienzos de siglo (Page, 2009), la persistencia de la dictadura puede reconocerse en varias películas de la década del 2000, con modulaciones diferentes de las que adquiría el tema en los años previos. En esta línea, Andermann escribe que la "abundancia de material que se ocupa de cuestiones de memoria (...) parece contradecir a primera vista el supuesto carácter de 'contemporaneidad absoluta' del nuevo cine argentino" (2015: 178). En el terreno del cine de ficción, Andermann señala que las películas se alejan de la alegoría predominante en los años ochenta "para acercarse a una representación más realista y descriptiva de la violencia dictatorial” (2015: 179), tal como puede verse en Crónica de una fuga.

Caetano construye una película "de género" y, en contraste con algunas de sus obras anteriores, trabaja con actores profesionales (Rodrigo de la Serna, Nazareno Casero, Lautaro Delgado y Pablo Echarri) y con un esquema de cine industrial (la película se realizó por encargo; entre las productoras estuvo 20th Century Fox de Argentina). Pero la principal diferencia con sus antecesoras es el contexto en que suceden los hechos: mientras Pizza, birra, faso, Bolivia y Un oso rojo comparten el paisaje de la crisis de fines de los noventa y principios de los 2000, en este caso el director elige mirar el pasado para narrar un episodio de la historia argentina reciente.

El contexto nacional se repone por medio de una placa informativa al principio: "El 24 de marzo de 1976 las Fuerzas Armadas argentinas dieron un golpe de es- 
tado...". Luego se precisa la fecha y el lugar en que comienza esta historia: "Buenos Aires, 23 de noviembre de 1977”. Si las películas de Caetano suelen tener coordenadas espaciales y temporales precisas -uno de los motivos por los cuales la crítica ha insistido en que su cine es realista-, aquí esos datos adquieren la exactitud del hecho real. La película transcurre entre 1977 y 1978, y el protagonista Rodrigo de la Serna encarna a una persona de carne y hueso: Claudio Tamburrini. ${ }^{3}$

Tamburrini, arquero del equipo de fútbol Almagro y estudiante de Filosofía en la Universidad de Buenos Aires, tenía 23 años cuando fue secuestrado. Permaneció 120 días en la Mansión Seré, centro clandestino de detención dependiente de la Fuerza Aérea, ubicado en Morón y conocido también como "Atila", según el nombre en código que le atribuían los represores (y que iba a dar nombre a la película, según contó Caetano en entrevistas).

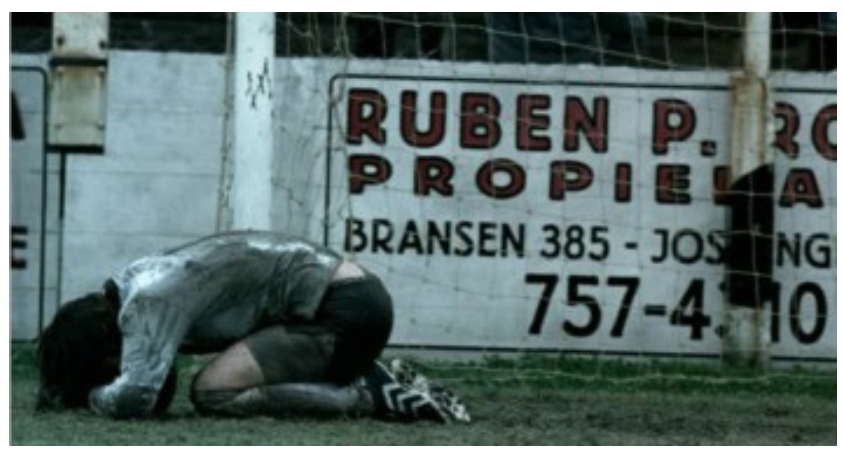

La película se presenta como una crónica, y en ciertos sentidos lo es: contabiliza con precisión el paso del tiempo por medio de placas cronológicas que van dividiendo el relato en capítulos y marcando la prolongación del cautiverio (“Día 1", “Día 75”, “Día 118”, etcétera). Ahora bien: en términos estrictos, la crónica remite a un estatuto de veracidad que no cabría aplicar a la película, ya que esta se asienta sobre una hibridez genérica que desdibuja las fronteras entre lo real (lo que efectivamente sucedió) y la ficción.

La historia se divide en tres grandes etapas. La primera, más breve, es la del secuestro de Claudio (tras un interrogatorio a él y a su madre, y un "allanamiento" en el que los represores matan a su perro y desvalijan la casa). En el libro, ocupa los primeros dos capítulos. En la película, funciona como una introducción, ya que el título del film aparece recién cuando Claudio ha entrado a la Mansión. En ambos textos, el destino del protagonista es anticipado en una frase en código pronunciada por los captores en comunicación con Atila: "Ya cayó el pájaro en la jaula. Vamos camino al nido".
La segunda etapa corresponde al encierro del protagonista y sus compañeros en la Mansión Seré, y funciona como un largo descenso al infierno. En el libro, esta etapa se divide en dos partes: "Casa de sombras" y "La pieza de los veteranos". Es en esta habitación de veteranos (como se denomina a quienes llevan mucho tiempo secuestrados) donde quedarán reunidos los cuatro prisioneros que protagonizarán la fuga: Claudio, Guillermo, Gallego (Lautaro Delgado) y el Vasco (Matías Marmorato). Con respecto al funcionamiento de estos personajes, los créditos de la película explican que, como parte del proceso de adaptación, la narración fílmica atribuye al Vasco acciones que en la versión original correspondían a dos personajes (el Vasco y Jorge). En la novela, el Vasco es asesinado, y quien participa de la fuga es el Chino, un personaje que no aparece en el film.

Finalmente, la tercera parte, anunciada desde el título, es la de la fuga, que abarca los últimos 8 capítulos del libro. Luego de un primer plan que fracasa y tras intensas discusiones entre ellos, los prisioneros deciden escapar por la ventana, atando las frazadas y utilizándolas para bajar hasta el jardín. Llamativamente, el narrador anticipa: "El plan era excelente, aunque un poco cinematográfico" (220). En esta tercera etapa, el film cambia de registro: la estética de la película de terror da paso a la del cine de aventuras, y el protagonista ya no es Claudio sino Guillermo, otro de los prisioneros.

\section{Testimonio y punto de vista}

Las dos versiones eligen comienzos ligeramente distintos. El libro comienza con un capítulo titulado " $\mathrm{AAl}$ magro de mi vida!” y relata, en tono despreocupado, la participación fallida del protagonista en un partido de su club (una desgracia que es apenas el preludio de otra desgracia mayor). En la película, en cambio, la narración no da ni siquiera esa tregua inicial: la primera imagen es un plano subjetivo de un joven (el Tano) que ha sido secuestrado por la represión ilegal, a quien le levantan la venda de los ojos para que "reconozca" una casa-la de la madre de Claudio-. Los represores no tardarán en ingresar allí en busca de "zurdos" y "terroristas". Luego veremos, en montaje alterno, unos segundos de Claudio, el protagonista, en situación de normalidad: primero jugando al fútbol, después viajando en colectivo.

No han pasado 8 minutos de película cuando el protagonista se encuentra con que un grupo de tareas ha irrumpido en su casa, dando comienzo al terror. Tras un 
interrogatorio acompañado de golpes -y de una frase que repiten ambos textos: "¿Así que sos arquero? A ver si atajás esta"-, la patota comandada por Huguito (Pablo Echarri) lo secuestra.

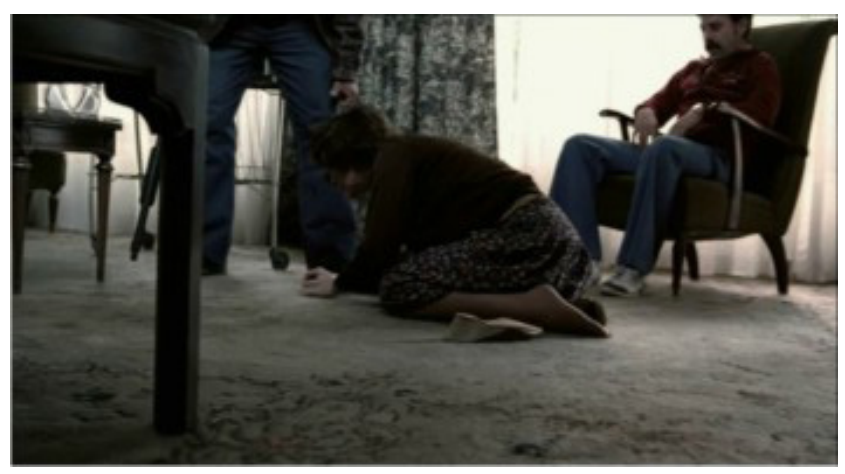

La película seguirá el punto de vista de Claudio (al que se suma, sobre todo durante la fuga, el de Guillermo), respetando así el hipotexto. Tamburrini explicita en su libro que la historia "está relatada desde el punto de vista privilegiado de un protagonista" y aclara que la perspectiva del texto "no tiene otra aspiración de validez objetiva que, simplemente, reflejar la visión del autor sobre los hechos" (10). La focalización cinematográfica en el personaje de Claudio se corresponde con la primera persona elegida por Tamburrini para su novela.

El testimonio exige, precisamente, la primera persona: es en función de la experiencia de ese sujeto-testigo-protagonista que la narración adquiere su fundamento. ${ }^{4} \mathrm{~A}$ diferencia de otros testimonios, el relato de Tamburrini no pretende hablar en nombre de las víctimas, sino a título personal: se trata, estrictamente, de la "visión del autor". Este testimonio no aspira entonces a volverse documento histórico, sino a narrar una experiencia, individual pero compartida: el recuerdo de Tamburrini se ha enriquecido con el de su madre y con el de Guillermo Fernández, según señala el autor al principio del texto.

El ambiente del centro clandestino de detención da lugar a una narración permeada de una violencia constante e impredecible. Las puertas de la Mansión marcan la frontera entre el afuera y el adentro, o lo que es lo mismo: entre la normalidad y el estado de excepción. Como les explica un guardia a los prisioneros: "El mundo de afuera ya no existe para ustedes. Este es un mundo subterráneo, oculto, sin leyes ni protección de ninguna especie. [...] Han caído en una fosa, donde ya no son personas" (37). El protagonista también señala ese contraste al escuchar desde su habitación algunos sonidos del exterior: "A escasos pasos de mi cuarto, la vida transcurre con normalidad, cansinamente, bajo el calor agobiante de la tarde" (43).

El oído es el sentido privilegiado en esta narración que, paradójicamente, ha sido trasladada al lenguaje audiovisual, regido por la imagen. Como el protagonista tiene los ojos vendados durante la mayor parte de la novela, la percepción se construye principalmente a partir de los sonidos: el tren, las voces de los guardias, los gritos de otros prisioneros, la televisión, etcétera. "El oído se ha convertido en nuestro sentido vital" (101), explica el narrador-protagonista. También se apela al olfato: "El aire del cuarto es irrespirable y nuestro aliento es más propio de cadáveres en descomposición, que de seres humanos vivientes" (63). Como veremos más adelante, en la película los efectos perceptivos de la limitación de la vista serán reconstruidos por medio del fuera de campo.

Una vez dentro de la Mansión Seré, Claudio descubrirá que su nombre fue entregado por el Tano, un joven al que apenas conoce y que, según sabrá después, acusó a Claudio solo para "ganar tiempo" para sus compañeros de militancia. En la novela nos enteramos de que el Tano había sido compañero de Claudio en la secundaria, cuando ambos militaban. La primera fase del cautiverio está marcada por la desconfianza recíproca entre los prisioneros y los reproches entre ellos ("¿Así piensan hacer la revolución ustedes? ¿Mandando en cana a personas que no tienen nada que ver?", le recrimina Claudio al Tano). Luego, a medida que pasa el tiempo, comienzan a generarse algunos lazos de solidaridad, incluso con los guardias, cuya ambigüedad moral es uno de los elementos más inquietantes en ambos textos.

La segunda fase del encierro corresponde a la tercera parte del libro ("La pieza de los veteranos") y comienza el "Día 31", según la cronología marcada por la película. Esta etapa implica un cambio de estatuto de Claudio como prisionero, cuando se incorpora a la habitación de los prisioneros más antiguos, justo para la Nochebuena. Recién entonces el protagonista es autorizado a sacarse la venda y ve, por primera vez, el rostro de Lucas. En esta segunda fase aparecen los personajes que acompañarán al protagonista en la fuga: Guillermo, el Gallego y el Vasco (en el libro, el Chino).

El "clima de terror constante" (66) es un elemento clave en la construcción del suspenso narrativo: en Atila nunca desaparece la sensación de imprevisibilidad. En la lógica del campo de concentración, no hay parámetros racionales que permitan medir las consecuencias de las acciones o posibiliten anticipar la reacción de los captores. Así, por ejemplo, cuando Claudio pide a los guardias 
cubiertos para comer, desata el terror y el enojo de sus compañeros: "Ahora nos van a reventar. ¿Qué te pensás? ¿Que estás en un hotel? Esas cosas acá no se piden”. La violencia puede estallar en cualquier momento: esa certeza erosiona a los prisioneros, y sostiene la tensión constante del relato. Recién hacia el final, cuando la guardia "metódica" restituya cierta previsibilidad para los protagonistas, estos serán capaces de anticipar el comportamiento de los vigilantes y planificar su fuga.

En el libro, el narrador en primera persona es consciente de la situación del país: "Miles de ciudadanos habían desaparecido. Otros tantos se encontraban en las cárceles del régimen a disposición del Poder Ejecutivo, sin causa ni sentencia" (43). Incluso se refiere a la Mansión como un "centro clandestino de detención" (62), lo que da cuenta de una interpretación precisa de los acontecimientos y de un conocimiento del contexto histórico que están ausentes de la película. De todos modos, el Claudio-narrador reconoce que el Claudio-personaje en ese momento no estaba al tanto de lo que pasaba: "Recluidos en Atila desde hacía meses, desconocíamos lo que sucedía fuera de la casa” (44).

En la película, el espectador no sabe hasta qué punto los personajes conocen la operatoria de la represión ilegal durante la dictadura: apenas acompaña su percepción -fragmentaria- de lo que sucede en el campo de concentración. En rigor, se trata de una diferencia temporal: la novela está narrada en pasado; el narrador reconstruye lo que le sucedió 23 años atrás, con toda la información que le ha proporcionado el paso del tiempo. La película, en cambio, está narrada en presente: el espectador acompaña el desconcierto de los personajes, quienes solo podrán reconstruir el marco histórico una vez que hayan escapado del centro clandestino, a partir de la investigación y los juicios realizados en democracia.

\section{Campo de concentración y nuda vida}

Cuando los guardias descubren que Guillermo les ha dado durante meses información falsa, las condiciones del encierro se deterioran aún más. Los detenidos son despojados de su ropa y atados desnudos a sus camas: la idea de escapar se vuelve entonces urgente para unos personajes que se van convirtiendo en muertos vivos, acostumbrados a la rutina enloquecedora del centro de detención. "Existe una relación directa entre las condiciones de cautiverio y nuestra propensión a la fuga. El empeoramiento de nuestra situación nos vuelve más proclives a intentar escaparnos" (199), explica el narrador-personaje.

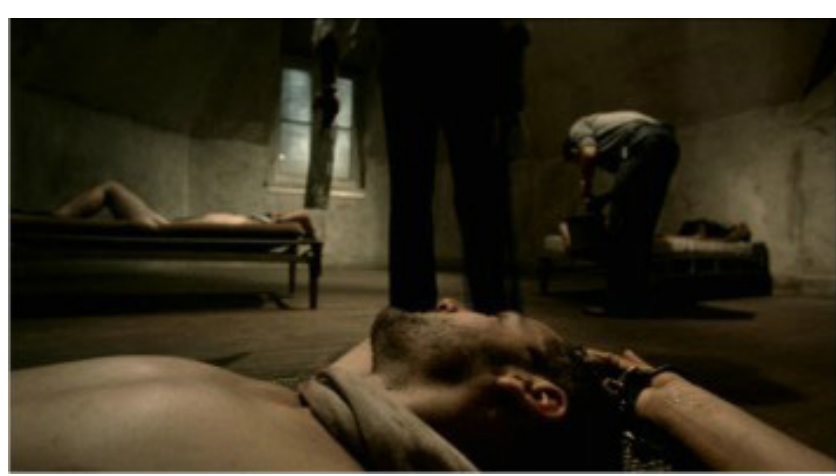

Liderados por Guillermo (en el film, Nazareno Casero) y por el propio Claudio, los prisioneros deberán poner en práctica aquello que el arquero señalaba en el vestuario en el comienzo de la película: el "sentido de equipo". El proyecto se menciona por primera vez el “Día 118” y se concretará el 24 de marzo de 1978, el "Día 121" en la cronología que la película establece a partir del secuestro de Claudio, mientras la dictadura militar cumplía su segundo aniversario.

El filme escenifica el período de mayor terror en la historia argentina reciente. La desnudez de los personajes durante los últimos días de encierro y durante la secuencia de la fuga hace explícito aquello que Agamben señala sobre el funcionamiento del poder biopolítico: "El estado de excepción [...] es precisamente aquel en que la nuda vida, que en la situación normal aparece engarzada en las múltiples formas de vida social, vuelve a plantearse en calidad de fundamento último del poder político" (2001: 15).

En la novela, esa progresiva reducción de los prisioneros a nuda vida es explicitada por primera vez cuando Claudio es despojado de su documento de identidad: "Se ha esfumado mi última posibilidad de ser identificado. Soy un bulto anónimo. He dejado de existir como persona" (78), afirma el narrador-protagonista. Poco después, compara a los prisioneros con "perros de Pavlov" (105), reducidos a los reflejos más básicos: el campo de concentración convierte a los sujetos en animales.

Reducidos prácticamente a su nuda vida, a los prisioneros les cuesta incluso reconocerse a sí mismos: cuando Lucas (Diego Alonso), uno de los guardias responsables del centro clandestino, los enfrenta con el espejo -desnudos, rapados, heridos y deteriorados por los meses de cautiverio-, ellos se rehúsan a mirar el reflejo de sus caras. "Afuera tampoco te reconocen", le advierte Lucas a uno de ellos, sugiriendo que el poder ha logrado 
transformar a sus rehenes en monstruos o bestias, y los ha vuelto irreconocibles, incluso para sí mismos. En una escena posterior, Claudio advierte a sus compañeros: "Estamos desapareciendo".

En la secuencia de la fuga, los cuerpos de los detenidos parecen definitivamente animalizados: se arrastran agachados (sólo en el tramo final los veremos de pie), con los brazos colgando delante, casi como monos, privados hasta de la ropa, el último elemento que los podría haber vinculado con la sociedad y la vida previa al encierro. "Hay que pensar como antes de entrar acá", dice Guillermo: para restituir la racionalidad, los personajes necesitan revertir la cosificación a la que los ha sometido la violencia demencial del centro clandestino.

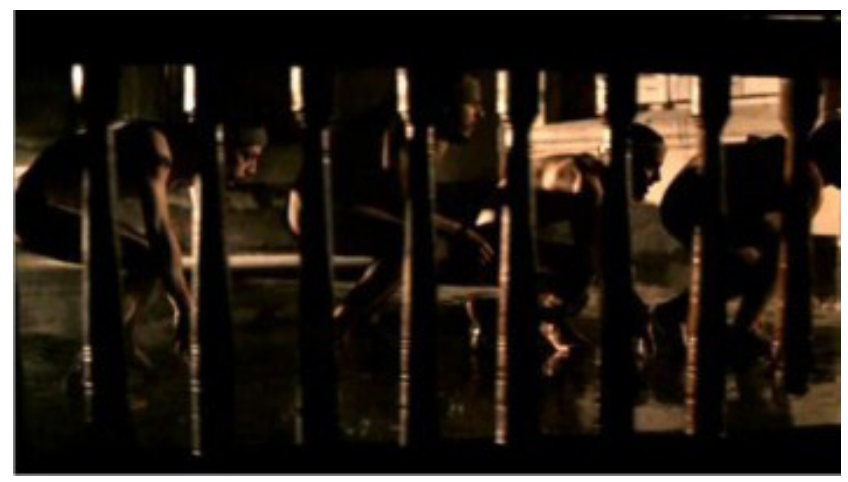

"Pensar como antes" implica recuperar la capacidad de percibir la situación en su totalidad. La percepción de los prisioneros tiene su correlato en los encuadres, fieles al punto de vista de las víctimas: durante el encierro casi no hay planos generales, sino que proliferan los planos detalle que dan cuenta de la percepción fragmentaria de los protagonistas. A la vez, el fuera de campo se potencia por medio de los sonidos percibidos por los personajes. En el libro, la percepción visual del protagonista es sustituida por recortes sensoriales e hipótesis acerca del entorno: "Estoy pisando pasto. Siento el rumor del follaje de unos árboles cercanos meciéndose en el viento. Parece ser un lugar descampado" (23), adivina Claudio.

Schwarzböck (2007: 41) sostiene que la "suspensión de la moralidad" que propone la película -y que es un rasgo propio del cine de terror-puede leerse en relación con el "estado de excepción” en que suceden los hechos: dentro del campo de concentración, la normalidad queda entre paréntesis. En la novela, esta anormalidad afecta incluso la percepción del tiempo, según afirma el protagonista en su primer día de cautiverio: "El tiempo de los habitantes de la casa marchaba a un ritmo distinto al del mundo exterior. [...] Sentí que ingresaba a una nueva dimensión temporal, en donde mi vida anterior se convertía en un recuerdo difuso y doloroso" (31).

\section{Ni héroes ni villanos}

La cámara de Caetano evita juzgar a los personajes; la discusión política queda fuera de la película y se escatima información con respecto a quiénes forman parte de organizaciones guerrilleras y quiénes no. Incluso los villanos -los guardias- aparecen en cierta medida humanizados por medio de algunos pequeños gestos, como brindar en Navidad con los prisioneros, jugar con ellos al truco o saludarlos cada mañana con un "Buen día" que, a los oídos del espectador, no puede sino sonar irónico.

El personaje más ambiguo es Lucas, quien es capaz de los peores maltratos pero por momentos actúa de manera paternalista y hasta le exige a su superior, Huguito, que "trate bien" a los detenidos. La construcción de $\mathrm{Hu}$ guito (a cargo de Echarri), en cambio, resulta un tanto caricaturesca: gomina, bigote, campera de cuero y un trato implacable constituyen casi el estereotipo perfecto de represor. En la novela, por otra parte, Huguito se define principalmente a partir de su voz "inconfundible", caracterizada por su "timbre potente" (46) ya que, a diferencia de Lucas, él no permite que los prisioneros vean su cara. El libro, además, menciona otros dos personajes que no aparecen en la película: Tanito, el miembro más violento de la "patota", y el Tucumano, cuyas acciones (por ejemplo, los juegos de cartas con los prisioneros) son atribuidas en el film al personaje de Lucas.

La galería de "villanos" se completa con el "juez", un personaje que aparece hacia el final del relato para darle un ultimátum a Guillermo, exigiéndole colaboración: "Yo soy el que decide si te matamos o te dejamos salir. [...] Te doy tres días para ordenar tus ideas. Y que nos des datos que nos sirvan. O abrís lo que tenés en la cabeza o te la abrimos nosotros". En la película, ese "juez" es interpretado por el Guillermo Fernández real, lo que genera una suerte de puesta en abismo de la narración: Fernández interpreta a un juez que interroga a Fernández; el protagonista del hecho histórico deviene actor en su transposición cinematográfica.

Víctimas y victimarios se abrazan al celebrar juntos los goles de Argentina que escuchan por la radio (en la novela, esa misma celebración nacionalista se da con motivo del triunfo de Carlos Reutemann en el Gran Premio de Brasil). En alusión a la conocida utilización del Mundial de 1978 por parte del gobierno militar, el deporte 
aparece aquí como una distracción que permite olvidar -al menos por un rato- el horror, y que parece "unificar" a los personajes detrás de una bandera común. En la novela, Tamburrini hace explícito el sentido político que adquirió aquel campeonato: "Para ellos, el Mundial de Fútbol era una magnífica oportunidad para lavarle la cara al régimen militar, aprovechando el exacerbado nacionalismo deportivo de sectores mayoritarios de la afición futbolística" (44).

En síntesis, en la película la construcción de los personajes coincide con la reclamada por el texto de Tamburrini: "La historia que se cuenta en este libro no es una historia de héroes y villanos". El "Prólogo" del libro busca diferenciarse de las "novelas fantasiosas" y asegura: "[L]os hechos verídicos son protagonizados por seres humanos de carne y hueso, con sus virtudes y defectos. Nunca por santos".

Tamburrini no habla de "personajes", sino de personas, y reivindica la ambigüedad y los matices en todos los sujetos involucrados en la historia que va a narrar: "El carácter testimonial de este relato requiere seres humanos reales, con sus angustias, sus temores, sus grandezas. Pero también con sus miserias, sus conflictos y rivalidades" (10). Así, por ejemplo, el narrador-personaje reconoce su propia tendencia a la "autoconmiseración patética” (92) y admite haber sentido "envidia” y "rencor liso y llano" (82) cuando liberan a Mario, su primer compañero de encierro. También describe la deshumanización a la que los ha sometido el campo de concentración: él y sus compañeros disfrutan la comida mientras escuchan los gritos de otros prisioneros torturados. En síntesis, no estamos frente a un héroe épico, sino ante un hombre con debilidades y ambivalencias.

Tamburrini reivindica una cierta suspensión del juicio: "Al escribir este libro, he renunciado a realizar un análisis político, o a ofrecer un relato ideológico de lo sucedido" (9, la cursiva es nuestra). El autor rechaza la posibilidad de que el relato sea utilizado políticamente ("Esa es la razón por la cual este libro ha debido esperar tantos años para ser escrito"), cuestiona el "prisma deformador de una ideología” y sostiene que el paso del tiempo le permitió abordar los hechos con "una cierta distancia emotiva". La distancia es a la vez temporal (Tamburrini escribe su libro 23 años después del secuestro) y emocional. Dicha distancia -que, Tamburrini aclara, "no significa indiferencia"- le imprime a la narración su condición de crónica y se traduce, en la película, en una puesta en escena que no juzga a ninguno de los personajes.
En el marco de esta suspensión del juicio moral que caracteriza a los dos textos, vale señalar que una de las principales diferencias entre ambos es que la novela testimonial aporta algunos datos en torno a la militancia de los personajes, mientras que esa información está ausente del film. De esta manera, en Crónica todas las víctimas quedan virtualmente equiparadas: el castigo es ilegal e inhumano para todos, independientemente de sus actuaciones políticas.

Como bien observa Schwarzböck, "[la] película no moraliza la suerte de los personajes, como lo haría si diera información sobre su pasado. El espectador solo puede conocer a cada personaje por lo que hace dentro del campo" (2007: 25). La novela, en cambio, sí marca una diferencia entre, por un lado, los personajes "inocentes" (aquellos ajenos a la militancia y la lucha armada) y, por el otro, "quienes, por propia voluntad, habían decidido correr el riesgo de ser capturados y torturados” (92).

En la película, cuando van a capturarlo a su casa, Claudio está totalmente desconcertado y asegura que él no pertenece a ninguna agrupación: eso es todo lo que sabremos sobre su compromiso político. En el libro, el protagonista reconoce haber militado "hace cuatro años” en la Federación Juvenil Comunista (entre 1972 y 1974), dato que la película omite. La novela también menciona su participación en la "Marcha del hambre" en 1972, durante el gobierno de facto de Lanusse, y su activismo universitario tras el golpe que derrocó a Salvador Allende en Chile en 1973. Además, nos informa que, el mismo día del secuestro, el protagonista tenía previsto deshacerse de "todo material comprometedor", sobre todo libros y volantes de la facultad, "resabios de la época más candente de su militancia política” (17).

En las charlas entre los veteranos, como en los interrogatorios, surgen las siglas que dan nombre a las distintas agrupaciones de la época: MIR (Movimiento de Izquierda Revolucionaria), ERP (Ejército Revolucionario del Pueblo), UES (Unión de Estudiantes Secundarios), etcétera. Uno de los capítulos de la tercera parte se titula, justamente, "Militancia": allí el narrador reconoce que todos los prisioneros de la pieza de los veteranos compartían la militancia política. En algunos pasajes, el narrador se muestra comprensivo con el activismo: "Éramos un grupo de jóvenes con conciencia social, buscando su rumbo en la vida, en el período más convulsionado de la historia argentina reciente" (107). Más adelante, apelando a la distancia que lo separa del presente del relato, el narrador desliza una autocrítica al plantear que él y sus compañeros estaban "presos del ideologismo más dogmático" (163). 
Al margen de los prisioneros y los guardias, en Crónica de una fuga y Pase libretambién hay lugar para otro tipo de personajes, que no caben en ninguno de los dos grupos: los vecinos. Cuando Claudio es secuestrado, señala: "Sentía las miradas de los vecinos a mis espaldas, que seguían el desarrollo de los hechos, atemorizados, detrás de las ventanas" (21). En algunos casos, los vecinos devienen colaboradores: por ejemplo, es gracias a un vecino que "les ha cedido la línea" (62) que la Mansión tiene teléfono. La presencia del centro clandestino en medio del barrio supone la extrema proximidad entre normalidad y estado de excepción, cuyas fronteras coinciden con las de la casa.

En la película, los vecinos son testigos mudos de la violencia. En estos personajes anónimos, que miran y escuchan pero no bablan, la indiferencia ha devenido complicidad con el régimen dictatorial. "Los vecinos también deben de escuchar nuestros gritos, cuando somos torturados" (64), razona el protagonista. Por medio de estos personajes, observadores y oyentes "neutrales" de la rutina del centro clandestino de detención, la película denuncia la actitud de buena parte de la sociedad durante la dictadura. Aunque también hay vecinos que ayudan a los prisioneros, como la mujer que les entrega ropa luego de la fuga (en el libro, esa vecina tiene nombre propio: Adela). En una de las escenas finales, cuando los protagonistas ya han escapado, la cámara -y con ella, el espectador- asume el punto de vista del vecino-testigo: mientras los personajes suben a un auto, los vemos a través de las rejas de la ventana de Adela, es decir, desde un hogar cualquiera ubicado cerca del centro clandestino.

\section{La representación del horror}

El principal dilema ético-estético que atraviesa la película puede sintetizarse en la siguiente pregunta: ¿cómo representar la tortura sin volverla espectáculo?

En ese sentido, las preguntas acerca de la figuración artística de hechos históricos traumáticos han sido moldeadas por los debates acerca de la representación del Holocausto en el cine, a partir de lo que Huyssen denomina la "globalización del discurso del Holocausto" (2002: 16). Autores como Huyssen y Baer (2006) defienden la legitimidad de construir ficciones a partir de un hecho histórico traumático, en contra de quienes sostienen que ficcionalizar el horror implica "espectacularizarlo", "estetizarlo", "falsear la realidad”, "banalizar los hechos" o promover una actitud voyeurista entre los espectadores.

La discusión sobre los modos de representación del pasado traumático suele presuponer algunos límites de lo aceptable, como la "estetización del horror" o la apelación a "lo obsceno". Rancière analiza este problema a partir del concepto de "imagen intolerable", retomando los análisis de Didi-Huberman sobre cuatro fotografías de Auschwitz. Según la posición de Rancière, es necesario deconstruir la presunción según la cual "el relato por la palabra" se opone radicalmente a la "imagen visible" (2010: 91). La cuestión de lo intolerable había sido planteada antes por Daney (2011) en su conocido ensayo "El travelling de Kapo", basado a su vez en un artículo de Jacques Rivette publicado en Cabiers du Cinéma sobre "lo abyecto" en el cine. "Abyecto", "obsceno" y "pornográfico" funcionan en buena medida como sinónimos en el trabajo de Daney. Para este autor, el gran referente moral en la representación cinematográfica de los campos de concentración es Alain Resnais y su Noche y niebla (1955), documental al que Daney define como "antiespectáculo" (2011: 12), construido a partir de material visual incautado a los nazis.

Al comparar documentales sobre el Holocausto con pretensiones "serias" (testimoniales, historiográficas) con las ficciones masivas (como La lista de Schindler, de Steven Spielberg, o La vida es bella, de Roberto Benigni), Baer apela a la eficacia de cada tipo de objeto: "Ni los primeros han sido tan convincentes, pedagógicos y sensibilizadores, ni los segundos han sido agentes del olvido colectivo o del falseamiento histórico" (2006: 143). Además, el autor reivindica el compromiso emocional que suscitan los dramas de ficción, frente a la mera racionalidad interpelada por el documento histórico.

En el plano de la forma, un elemento clave en el análisis de Baer tiene que ver con el punto de vista que construye la ficción. Aquí la pregunta principal es con quién se identifica el espectador: ¿con las víctimas o con los victimarios? Según las conceptualizaciones aristotélicas clásicas, la identificación abre la posibilidad de una catarsis en el desenlace. El autor también se detiene en el "efecto de realidad" logrado por las películas sobre el Holocausto y reconoce que algunas de ellas han funcionado a la manera de "documentos", a partir de una superposición de lo real y sus representaciones en el imaginario social. La verosimilitud de esas imágenes sería más un efecto de intertextualidad que de adecuación al referente: Baer alude a una "memoria de las imágenes", para la cual "el referente histórico ya no es el acontecimiento, sino su representación, es decir las fotografías, los documentales y el cine" (2006: 132). 


\section{El horror (histórico) como terror (cinematográfico)}

Crónica de una fuga dialoga explícitamente con el género de terror. Esta opción estética, que pone en tensión la idea de una representación "realista", invita a reflexionar sobre los modos en que la ficción audiovisual construye memoria. La originalidad de la mirada de Caetano radica en haberse atrevido a hacer una película sobre el terror (real) de la dictadura, apelando a algunas convenciones del género (ficcional) de terror.

Esa tensión entre realismo y género ficcional ya estaba presente en Pase libre. El texto de Tamburrini tiene un estatuto híbrido: se presenta como "novela testimonial", es decir, es a la vez testimonio y novela. Por un lado, el "Prólogo" subraya el "carácter testimonial del relato" y enfatiza reiteradamente su fidelidad a lo sucedido en la realidad: "[Este libro] relata un hecho verídico sucedido a fines de los años 70, en pleno apogeo de la última dictadura militar en Argentina" (9). Incluso explicita su intención de dejar de lado el "análisis político", la "ideología”, los "preconceptos", en pos de presentar los hechos "por sí mismos", y argumenta: "La realidad es siempre más elocuente que cualquier modelo de pensamiento".

Por otro lado, la contratapa señala que se trata de una "novela de carácter autobiográfico", escrita "como un thriller de factura cinematográfica": estamos ante una historia (real) relatada con la mediación de un género ficcional (el thriller), y cuya escritura ya revestía un carácter "cinematográfico". Asimismo, presentar el texto como novela testimonial en lugar de testimonio implica dejar abierto un espacio para la ficcionalización: ese espacio es ocupado principalmente por los capítulos protagonizados por Adela, una vecina de la Mansión, en los que Tamburrini imagina el pasado de la casa, cuando estaba habitada por la familia Seré.

Algunos de los elementos que permiten emparentar a Crónica de una fuga con el género de terror son la iluminación opresiva de la habitación-celda, la distorsión de los sonidos, las puertas que se abren -y que siempre anuncian la llegada del victimario-, el juego entre lo que se ve y lo que se retacea por medio de las vendas que cubren los ojos de los protagonistas, y el suspenso permanente, correlato de la incertidumbre en la que están hundidos los personajes: nunca se sabe cuándo puede tocar una nueva sesión de tortura, las conductas de los guardias son tan arbitrarias que resulta imposible prever las consecuencias del más mínimo acto.

A los recursos mencionados se suma la luz intermitente de los rayos y el sonido de los truenos durante la tormenta espectacular que se desata durante la fuga de los prisioneros, y los encuadres que agigantan la ventana desde donde se realiza el escape. La Mansión Seré es casi un personaje más de la película -de hecho, en las placas finales que explican qué fue de la vida de los cuatro protagonistas, hay una dedicada a la casa-, lo que coloca a la película en sintonía con una tradición particular del género de terror: el gótico.

En los relatos góticos (basta mencionar, por ejemplo, "La caída de la casa de Usher" de Edgar Allan Poe) hay siempre una casa maldita, suntuosa pero decadente, que está aislada de la ciudad y funciona como espacio del horror y la desolación. Los encuadres de la fachada de la Mansión en Crónica de una fuga, generalmente contrapicados, construyen esa atmósfera lúgubre, que permite adivinar que en el interior de ese edificio majestuoso suceden los acontecimientos más sórdidos. Muchas narraciones góticas terminan con la destrucción de esa casa maldita: aquí apenas llegamos a atisbar, al final, cómo empieza a desmontarse el centro clandestino, que los militares luego incendiarán para eliminar toda evidencia tras la fuga de los cuatro prisioneros. Mientras la película recurre al gótico, el libro apela más bien a la imaginería religiosa: allí se compara la Mansión con el "infierno" y se la describe como un "reino de sombras" (58).

El recurso fundamental al que apela Caetano para inscribir su película en el género de terror es el fuera de campo. De manera consistente a lo largo del film, el director elige no mostrar las escenas de tortura -que hubieran hecho virar la película desde el género de terror al cine gore-, aunque sí permite que las escuchemos. En cierto sentido, la apelación a aquello que no se ve emparenta al espectador con los protagonistas, quienes viven con los ojos vendados. El sonido sin imagen acrecienta los efectos del terror: oímos los golpes, pero no sabemos en qué parte del cuerpo ni con qué objetos se ejecutan; sentimos los gritos pero no vemos la sangre, aunque sí las cicatrices y los moretones que marcan los cuerpos después de esas sesiones.

Como consecuencia de que no vemos la violencia, tampoco llegamos a acostumbrarnos a ella. El sadismo de la tortura se despliega sólo en la imaginación del espectador: al escatimar la violencia física, la película logra una conmoción mayor de la que habría obtenido al regodearse en mostrar la agresión. Esta decisión estética es también una opción ética: Crónica de una fuga no admite un espectador morboso. $\mathrm{Y}$ construye, como explica Schwarzböck, uno que se identifique con los protagonistas: "La originalidad (...) está en valerse de códigos del 
género de terror sin por eso usar su sistema de catarsis. ${ }^{5}$ En el filme de Caetano, el espectador tiene que identificarse con el dolor de la víctima y no con el placer del victimario" (2007: 53).

En el testimonio, en cambio, el lector asiste a descripciones minuciosas de las sensaciones experimentadas por el protagonista durante las sesiones de tortura:

Otro golpe de corriente; esta vez, en el brazo derecho. Siento como si una cuchillada me abriera la carne. Antes de que el cuerpo deje de temblar, llega el nuevo sacudón eléctrico. Es un dolor punzante, que se mete en las extremidades y llega hasta el hueso. Se hace una pausa. Aprovecho el momento de respiro para ordenar mis ideas. Siento un pánico incontrolable. Grito de manera desaforada al ser picaneado y, al interrumpirse la tortura, comienzo a llorar desconsoladamente. Noto que eso les provoca irritación, pero no puedo controlarme. El miedo decide por mí. (25)

En la novela, las sesiones de tortura -incluso las vejaciones más humillantes- no solo son objeto de descripciones detalladas, sino también de la reflexión del protagonista. Por ejemplo: "El desorden de una sesión de tortura favorece al interrogado" (48); "Paradójicamente, durante la tortura, el deseo de sobrevivir se concilia con el interés altruista por los demás" (50); "Compartida con otro, la picana se hace menos pesada que las veces anteriores" (52). Todas estas ideas del personaje están ausentes de la película: allí no accedemos a su mundo interior.

En este punto aparece otra de las diferencias fundamentales entre la novela y la película. Si el relato de Tamburrini puede explayarse sobre la tortura no es porque las palabras sean menos gráficas que las imágenes, sino por su condición de testimonio en primera persona: no puede haber sadismo en el relato de una víctima. Esa opción no era viable para la película de Caetano: aunque el film mantenga la focalización en el personaje de Claudio, la primera persona del testimonio es imposible de trasladar al cine, donde la instancia de enunciación adquiere siempre la forma de una tercera persona (con excepción de algún experimento como La dama del lago, de Robert Montgomery, filmada íntegramente en planos subjetivos). En consecuencia, la representación de la tortura -la picana, el "submarino", los golpes-admite en el libro un nivel de explicitud y detalle que la hubieran vuelto espectáculo morboso en la película.

\section{Comentarios finales}

En definitiva, la gran paradoja de Crónica de una fuga es que representa la violencia de la dictadura sin es- pectacularizarla, sino más bien retaceándola. La cámara de Caetano no se obsesiona con la agresión física, sino que la administra por medio del uso del fuera de campo. Aunque la historia pueda conmover al espectador y logre su identificación con el protagonista, la puesta en escena tiende a la suspensión de la moralidad: de esa manera, Caetano elude el sensacionalismo y la espectacularización, opciones que hubieran contribuido a naturalizar esa violencia a los ojos del espectador.

El director transgrede la solemnidad del subgénero "película sobre la dictadura" y, en vez de ofrecer un drama testimonial, realiza una película que apela al género de terror para contar la violencia de la represión ilegal, y cuyas expectativas están puestas desde el comienzo en la fuga, garantizada por el título del filme (y por su afiche, que anuncia: "4 jóvenes. 120 días. Una oportunidad"). Caetano sustrae las imágenes de la tortura y apuesta a la potencia del sonido y a la imaginación del espectador: de ese modo, evita que la violencia se cosifique y se vuelva espectáculo.

Luego del secuestro, el cautiverio y la fuga, la narración ofrece un happy end a medias. Los prisioneros se fugan, pero el espectador sabe que constituyen una excepción: el relato histórico indica que 30.000 personas no lo lograron. Las placas informativas del final resumen el destino de cada personaje y reseñan la participación de los protagonistas en el Juicio a las Juntas de 1985. El texto de Tamburrini, en cambio, reconoce que no supo nada más de sus compañeros tras el cautiverio, con excepción de Guillermo, con quien sostiene "una inquebrantable amistad de más de dos décadas" (7).

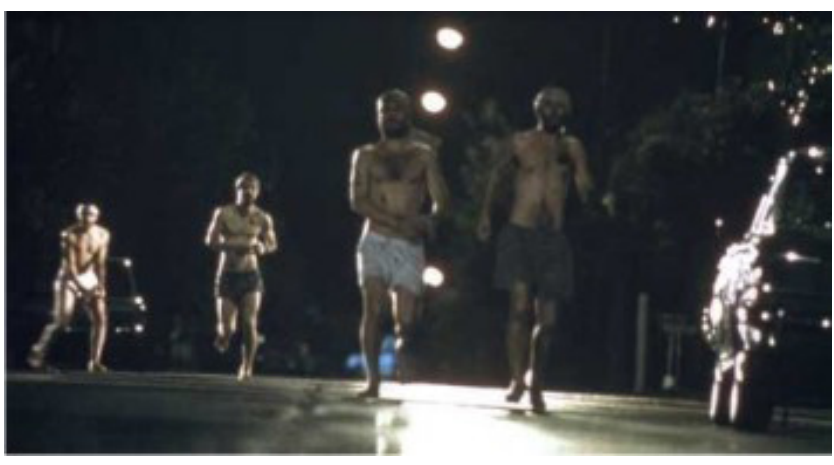

Por otro lado, en la última escena de la película, Claudio se encuentra en la estación de tren con la mujer a quien había cedido el asiento en el colectivo al principio de la película, justo antes que lo secuestraran. En aquel primer encuentro, la mujer estaba embarazada; en este último, ya ha dado a luz y espera el tren con su bebé. Esta imagen final señala que la vida sigue: al evocar el va- 
lor de la paternidad (recurrentemente afirmado en el cine de Caetano), se afirma la posibilidad de que el futuro sea diferente, mediante la transmisión del legado de aquello han vivido y sufrido los protagonistas de esta historia.

Esa esperanza que sostiene el desenlace es la que nace de la memoria, reivindicada también por Tamburrini en el "Prólogo" de su libro: "Es mi ambición que este libro contribuya a un debate sin preconceptos sobre los mecanismos que posibilitaron la ocurrencia de fenómenos como los narrados en estas páginas. No conozco antídoto mejor para evitar la repetición de estos hechos".

La intención explícita de Tamburrini es que, al hacer presente un hecho del pasado, su texto funcione como antídoto, como modelo de comprensión que per- mita actuar de manera preventiva sobre el futuro. No se trata solo de visibilizar lo sucedido, de denunciar o hacer catarsis, sino que el autor aspira a construir una "memoria ejemplar" que permita intervenir sobre el presente: "El uso ejemplar [de la memoria] permite utilizar el pasado con vistas al presente, aprovechar las lecciones de las injusticias sufridas para luchar contra las que se producen hoy día, y separarse del yo para ir hacia el otro" (Todorov, 2000: 30).

Por medio de la memoria, estos textos -el de Tamburrini y el de Caetano- señalan la posibilidad de un legado, de que quienes vienen atrás construyan una realidad diferente. Esa herencia deja abierta, en historias asfixiadas por un presente insoportable, una grieta hacia el futuro.

\section{Referencias}

Agamben, Giorgio (2001). Medios sin fin. Notas sobre la política. Valencia: Pre-textos.

Aguilar, Gonzalo (2010). Otros mundos. Un ensayo sobre el nuevo cine argentino. Buenos Aires: Santiago Arcos.

Andermann, Jens (2015). Nuevo cine argentino. Buenos Aires: Paidós.

Baer, Alejandro (2006). “El cine y la televisión: el horror en pantalla”. En Holocausto. Recuerdo y representación. Madrid: Losada.

Daney, Serge (2011). "El travelling de Kapo”. En AA.VV. Diálogos sobre la ética de la representación cinematográfica. Buenos Aires: OPFyL.

Huyssen, Andreas (2002). "Pretéritos presentes: medios, política y amnesia". En En busca del futuro perdido. Cultura y memoria en tiempos de globalización. México: FCE.

Jelin, Elizabeth (2002). Los trabajos de la memoria. Madrid y Buenos Aires: Siglo XXI.

Mullaly, Laurence (2009). “La (est)ética del margen en el cine de Adrián Caetano”. En Pandora, No 9, Saint-Denis, pp. 149-162.

Page, Joanna (2009). Crisis and Capitalism in Contemporary Argentine Cinema. Durham y Londres: Duke University Press.

Rancière, Jacques (2010). “La imagen intolerable”. En El espectador emancipado. Buenos Aires: Manantial.

Sarlo, Beatriz (2005). Tiempo pasado. Cultura de la memoria y giro subjetivo. Buenos Aires: Siglo XXI.

Schwarzböck, Silvia (2007). Estudio crítico sobre Crónica de una fuga. Buenos Aires: Picnic.

Todorov, Tzvetan (2000). Los abusos de la memoria. Barcelona: Paidós.

1 De aquí en adelante, las citas del texto corresponden a la siguiente edición: Tamburrini, Claudio (2006). Pase libre. La fuga de la Mansión Seré, tercera edición. Buenos Aires: Continente.

2 Tal vez la única excepción sea Francia (2009), una película centrada en el universo familiar y el esfuerzo cotidiano de sus protagonistas por sobreponerse a los problemas económicos y sentimentales.

3 Para mayor claridad, en este trabajo nos referiremos al autor de Pase libre como "Tamburrini”, y al personaje (de la novela y la película) como "Claudio".

4 Sarlo propone una crítica del testimonio a partir de la crítica del sujeto realizada por la deconstrucción y el posestructuralismo, y plantea una paradoja: "La actualidad es optimista y ha aceptado la construcción de la experiencia como relato en primera persona, aun cuando desconfíe de que todos los demás relatos puedan remitir de modo más o menos pleno a su referente” (2005: 49). En ese sentido, para Sarlo la primera persona produce una ilusión referencial.

5 Schwarzböck (2007) se refiere a que el género de terror demanda que el espectador se distancie de la desgracia de las víctimas y, en sus versiones más contemporáneas, incluso se identifique con el asesino. 